Institute for Research on Poverty

Discussion Paper no. 1196-99

\title{
Migration and the Employment and Wages of Native and Immigrant Workers
}

\author{
Franklin D. Wilson \\ Center for Demography and Ecology \\ University of Wisconsin-Madison \\ E-mail: wilson@ssc.wisc.edu \\ Gerald Jaynes \\ Department of Economics \\ Yale University
}

September 1999

Analysis for this paper was supported by a Center Grant from the National Institute of Child Health and Human Development to the University of Wisconsin-Madison, Center for Demography and Ecology (5P30-HD05876), a grant to the University of Chicago and the University of Wisconsin-Madison (R01HD25588), and a grant from the Mellon Foundation.

IRP publications (discussion papers, special reports, and the newsletter Focus) are now available on the Internet. The IRP Web site can be accessed at the following address: http://www.ssc.wisc.edu/irp/ 


\begin{abstract}
This paper assesses the association between migration (both international and internal) and the employment status and earnings of young noncollege-educated native white, black, Hispanic, Asian, and immigrant white-collar and blue-collar workers in the United States during the decade from 1980 to 1990. We seek to determine (1) whether internal and/or international migration contributed to the increased joblessness observed for blacks, Asians, and Hispanics in the 1980s, particularly among males, and (2) whether migration contributed to the decline in the hourly wages of both native and immigrant workers in the 1980s. We present results which only partly support the claim that internal migrants and immigrants are substitutes for native workers. On the one hand, we find that migration (flow) was not a major factor associated with the increased joblessness and decreased wages experienced by some native groups during the 1980s, particularly among blue-collar workers. On the other hand, we do find that changes in the foreign-born composition of an industrial sector (a measure of immigrant stock) were associated with increased joblessness of native workers and decreased joblessness of immigrant workers.
\end{abstract}




\section{Migration and the Employment and Wages of Native and Immigrant Workers}

This paper reports estimates of the association between internal and international migration and the wages and employment of young native and immigrant noncollege-educated workers in the United States. Massive immigration during the last quarter century raises concerns that the newcomers are a substitute labor supply for native workers. Whether or not immigrants adversely affect labor market outcomes of native workers is receiving increased attention from social scientists (see Borjas, 1994; Muller, 1993; Borjas and Freeman, 1992; Bean and Fossett, forthcoming; Espenshade, forthcoming). Despite repeated surveys indicating that most Americans believe that immigrants take jobs from and lower the wages of natives, most cross-sectional studies of intermetropolitan variation in employment and earnings of natives indicate little or no adverse effects from immigration (see Borjas, 1994). But Jaeger (1995) reports that increases in the immigrant share of the labor force during the 1980s accounted

for 6 percent of the increase in the college/high-school wage differential, and that immigration caused a 3 to 5 percent decrease in the wages of high school dropouts in the aggregate of the 50 largest metropolitan areas (see also Butcher, 1998). Similarly, Borjas, Freeman, and Katz (1992), employing time-series analysis to estimate the macro impact of immigration, concluded that immigrants with lower educational attainment were partly responsible for the relative decline in the wages of native workers with similar levels of education (see also Borjas, 1998); findings by Borjas (1992) of relative declines in the skill levels of recent immigrants suggest that such effects may become long-term.

Results from previous studies have been compromised by problems related to reliance on a single data source for the measurement of key variables, the particular way in which labor market outcome variables are measured, the appropriateness of instruments for evaluating the effects of migration, and weak controls for labor demand and supply conditions prevailing in metropolitan labor markets. These issues are discussed in greater detail below. Our analysis compares differences in the levels of joblessness and earnings, within two broad occupational categories, among young noncollege-educated 
native black, Hispanic, Asian, and non-Hispanic white workers, and recent and long-term immigrant workers living in 52 of the largest consolidated metropolitan statistical areas (CMSA)/metropolitan statistical areas (MSA), and working in one of three major industry sectors. Two questions guide the analysis. First, did internal migration and immigration contribute to the increased joblessness observed for black, Hispanic, and Asian workers in the 1980s, particularly for men? Second, did migration contribute to declining wages for native workers in the 1980s? Much of the debate about "immigration effects" has evolved out of efforts to explain the continued weak and marginal labor market position of African Americans living in major American cities, some of which have experienced substantial immigrations flows in the past two decades (Wilson, 1996; Borjas, 1998). For example, Borjas (1998) suggests that African Americans, relative to other native groups, suffer a net loss in economic well-being due to immigration. This occurs because African Americans own few capital resources which could complement immigrant labor, and because the skill distribution of the African-American population is similar to that of immigrants, rendering them competitors and thus at risk of displacement.

We briefly review several hypotheses about the association of immigration with the labor market status of native workers. Next, we explain why further analysis of this relationship is necessary, and we discuss the particular approach applied in this paper. We then present results supporting both the claim that internal migrants and immigrants are complements and the claim that they are substitutes for native workers. We conclude that migration (flow) was not a major factor associated with the increased joblessness and decreased wages experienced by some native groups during the 1980s, particularly among blue-collar workers. 


\section{BACKGROUND}

There appears to be general agreement that the labor market status of white-collar and skilled blue-collar workers has not been adversely affected by the influx of immigrant workers (see Smith and Edmonston, 1997; Borjas, 1990, 1994; Muller, 1993; Muller and Espenshade, 1985). However, a number of arguments have been advanced to explain why immigration's effects on the unskilled may differ from its effects on skilled labor. First, relative to the demand for unskilled labor, the demand for skilled workers continues to increase, allowing skilled immigrants to be more readily absorbed into labor markets. Second, skilled native workers, fluent in the English language and familiar with prevailing cultural practices, enjoy a decisive advantage over most immigrants in the labor market. In addition, certification or licensing, as well as apprenticeship and examination, is often required to gain entry to skilled occupations and jobs. Even when immigrants have received occupation-specific training before arrival, they still may not meet standards acceptable in the United States. Finally, some evidence suggests that because immigrants increase the demand for goods and services, their arrival may result in a disproportionate increase in employment opportunities for skilled native workers (Mueller and Espenshade, 1985).

In contrast to conditions for skilled employment, immigrants can more easily substitute for unskilled workers, since little or no training is required for unskilled jobs. Additionally, given declining employment opportunities for low-skilled blue-collar workers (see Kasarda, 1995; Wetzel, 1995), employer preferences for low labor costs and immigrants' presumed willingness to work for lower pay make the potential for competition and job displacement much greater in the case of low-skilled native workers (Bailey and Waldinger, 1991a). Bonacich's $(1972,1976)$ split labor market model, which was developed to account for the antagonism of white workers toward black workers in U.S. cities in the 19th and early 20th centuries, can also be applied to the relations between employers and native and immigrant blue-collar workers. 
If employers are faced with two groups of workers who differ considerably in their potential for labor militancy over wages, benefits, and working conditions but are similar in other productivity characteristics, employers are likely to select workers from the least militant group on the grounds that these workers are less likely to disrupt the production process. Immigrants are considered to be in a weaker bargaining position because they often have fewer alternative means of support, and their expectations about labor remuneration may be lower because their reference is the prevailing wage and benefit structures in their country of origin. Moreover, once immigrants establish a presence in an industry/occupation their numbers are likely to increase through referral and networking (see Waldinger, 1994; Bailey and Waldinger, 1991a, b). In this context, immigrants may become the preferred workers, particularly in industries with low profit margins and those in which employers have few relocation options available to them. An alternative interpretation of native/immigrant differences in joblessness among the less skilled is that immigrants are willing to take jobs natives will not take, either because of low wages, poor working conditions, or access to alternative sources of income (see Welch, 1990; Mead, 1992). Support for this explanation is partly provided by the high joblessness of native workers in major cities that have experienced substantial declines in blue-collar jobs in manufacturing but substantial increases in low-wage service jobs taken by immigrants (Bailey and Waldinger, 1991a). It is also possible that immigrants, through entrepreneurial activities, create employment opportunities for others from a similar origin (Portes and Rumbout, 1996).

\section{$\underline{\text { Internal Migration and Ethnicity }}$}

Analyses of immigration's labor market effects have been based on a simple idea. If immigration has negative effects, then, other economic factors constant, employment conditions of native workers should be worse in areas with relatively more immigrant workers. Hence, much research compares the wages (employment status) of native workers in labor markets with few immigrants to those with relatively many immigrants. If other economic factors have been sufficiently controlled, a good estimate 
of the independent effect of immigration is obtained. But few studies have reported reductions in earnings and/or increased joblessness among native workers that can be attributed to immigration of more than 2 percent (see Borjas, 1994; Friedberg and Hunt, 1995; Smith and Edmonston, 1997).

Some researchers believe that negative effects have not been found because native workers whose wages or employment would have been worsened by immigration leave areas receiving large numbers of immigrants (Walker, Ellis, and Barff, 1992; Frey, 1995; White and Hunter, 1993). Frey (1995) reports that less-skilled black and white native workers have high outmigration rates from areas that attract large numbers of immigrants; the natives appear to migrate to places with few immigrants. If these findings are plausible, the comparative model underestimates immigration's effect on native workers for two reasons. First, average employment conditions for native workers in areas with high numbers of immigrants may remain stable or rise because some natives leave for other destinations. Second, those leaving areas of high immigration for areas of low immigration increase the labor supply and may worsen employment conditions in their areas of destination. These behaviors may cause employment conditions for natives in areas of high immigration to be greater than expected, but lower than expected in areas of low immigration but high net internal migration. Based on these observations and empirical findings, it is clear that efforts to estimate the effects of immigration on labor market outcomes must simultaneously consider the potential effects of internal migration.

It is also possible that migrants are attracted to areas of modest to strong economic growth, making it difficult to distinguish the effects of immigration on the labor market outcomes of native workers from that associated with economic conditions. If migrants respond to favorable employment conditions at destination, then competition with and displacement of native workers may not occur, because of tight labor market conditions. Thus, higher joblessness and low wages among native workers may be more pronounced where economic conditions are stagnant and the volume of immigration is low. 


\section{CURRENT RESEARCH}

The research reported here is designed to consider some of the factors discussed above. By combining several alternative data sets with 1980 and 1990 census data, we compute estimates of the effects of internal migration and immigration on the labor market status of young, noncollege-educated native and resident immigrant workers during the 1980s. We pursue this task by estimating the association of immigration and internal migration with interindustry/metropolitan area variation in 1980-1990 changes in the predicted probability of joblessness (unemployment and labor force nonparticipation) and 1979-89 changes in predicted hourly wages for different native ethnic/immigrant groups by occupation.

The analysis presented below attempts to address some of the problems that have plagued previous research on this issue. Specifically, previous studies have been compromised by problems related to the particular way in which labor market outcome variables have been measured, the appropriate instruments for evaluating the effects of migration, and weak controls for labor demand and supply conditions prevailing in metropolitan labor markets. Our attempt to address most of these problems is discussed in greater detail below. ${ }^{1}$ The analytic model used here is structured to provide insight into the question of whether the effect of migration on labor market outcomes differs for native African-American, Asian, Hispanic, and white workers and two categories of immigrant workers distinguished by length of residence in the United States, who were employed in similar occupations and industry sectors. Thus, in contrast to much previous work, we expand the focus of the analysis to include the effect of migration on the labor market status of Hispanics, Asians, and immigrants themselves. ${ }^{2}$

We hypothesize that within occupations and industry sectors, the association of migration with labor market outcomes will differ for members of these different groups, net of the influence of group differences in demographic and human capital attributes and of structural factors associated with labor demand and supply conditions prevailing in local labor markets. Specifically, consistent with a 
preferential ordering of similarly skilled workers by employers, we expect that the level of joblessness (unemployment and labor force nonparticipation) among African Americans and Hispanics will be higher given a greater volume of migration of minority populations. On the other hand, because migrants (immigrants in particular) are expected to have lower reservation wages than natives, we expect that the relative earnings of recent migrants will be lower than those of native workers given high levels of migration of minority populations. We assume further that migration is associated with an increase in the labor supply, potentially resulting in slack labor market conditions, in which competition among workers with similar labor inputs as migrants will lead to higher joblessness and reduced hourly wages.

\section{$\underline{\text { Data and Methods }}$}

The sample universe consists of men and women wage and salary workers aged 19 to 34 who were not enrolled in school, not married, not disabled, and had completed no more than 12 years of schooling. During the 1980-90 period, this group experienced the highest level of joblessness and the largest decline in earnings. The demand for workers with no postsecondary education declined dramatically, and during this period, the United States experienced a substantial inflow of immigrants who were similarly disadvantaged. Hence, our expectation of a negative effect of migrants, both internal and international, reflects the declining demand for low-skilled workers in the face of a constant or an increased supply of such workers.

Variables

Dependent Variables. The dependent variables used in this analysis are 1980-90 changes in the mean predicted probability of joblessness and of hourly wages for six ethnic/immigrant groups stratified by two broad occupational categories and three industrial sectors, and living in one of 52 large metropolitan areas in 1980 and 1990. The predicted values are estimated as follows. First, using data from the 1980 and 1990 Public Use Microdata Samples (PUMS), we estimate 156 equations (52 MSAs 
and three major industry sectors), separately for 1980 and 1990, for joblessness and hourly wages, for samples of nonfarm wage and salary workers aged 19 to $64 .{ }^{3}$ Second, we use the estimated coefficients from these equations to calculate mean predicted values for the probability of joblessness and hourly wages for African Americans, Asians, Hispanic, whites, and two immigrant subgroups aged 19 to 34, who were not in school, not married, not disabled, and had no more than high school education. These mean predicted values are stratified by occupation (white-collar, blue-collar), industry (primary, secondary, tertiary), metropolitan area of residence (52 areas), and year $(1980,1990)$.

We use predicted values to ensure that labor inputs (and changes in labor inputs) for the young men and women of the six ethnic/immigrant groups included in the analysis of change are identically based on the relative market valuation of individual attributes known to affect joblessness and wages. We claim that the dependent variables used here are preferable to such gross measures as employment/population ratios, unemployment (or jobless) rates, and/or average hourly wages of metropolitan workers, because they are derived from an estimation equation that includes all workers 19 to 64 years old. Thus, our approach to analyzing changes in the labor market status of workers aged 19 to 34 implicitly takes into account the relative standing of these workers with respect to other workers with different attributes.

The metropolitan areas included in this analysis were selected based on the presence of at least 1,000 sample respondents in the 1990 PUMS (5 percent sample) who are either native black, Hispanic, or Asian, and in which there are at least 500 foreign-born workers in the appropriate age group, and for which information is available on other files used in this analysis. For a number of these metropolitan areas, the PUMS files do not provide representative samples of their populations. The underrepresentation occurs because identifying the population of an excluded area would have violated confidentiality rules. ${ }^{4,5}$ 
Explanatory Variables. The explanatory variables whose effects are of particular interest include: Minority Net Migration, 1980-88, of blacks, Hispanics, and Asians to a metropolitan area; Minority Immigration, 1980-88, to a metropolitan area; Foreign-Born Share, the percentage of the labor force of a major industry sector that is foreign born in 1980; and 1980-90 Change in Foreign-Born Share, the ratio of the percentage of an industry sector's labor force that was foreign born in 1990 to its 1980 percentage. Minority Net Migration combines an estimate of internal migration derived from income tax records with estimates of the number of persons receiving permanent resident alien status, the number of refugee arrivals, and an estimate of the number of undocumented international migrants entering the country between 1980 and 1985 (see U.S. Bureau of the Census, 1989, for a detailed discussion of the methodology). Through linear projection, we extend the estimates to cover the period through $1988 .^{6}$ Although much of the debate about negative impact links immigration with the labor market status of native workers, we think a case can be made for considering internal migrants as well. First, immigrants do engage in secondary internal moves (see Bean and Tienda, 1987). Second, internal migration streams may also contain substantial numbers of illegal immigrants, some of whom are included in surveys and administrative records. Finally, poorly educated and unskilled native workers can also migrate and compete effectively against long-term residents of a local area with similar labor market skills and experiences.

Our expectations are that high levels of net in-migration, whether internal or international in origin, of blacks, Hispanics, and Asians over the 1980-88 period will increase the level of joblessness among native workers and lower their wages. This expectation is based on the assumption that internal migrants and immigrants are willing to work for lower wages and few fringe benefits, and under worse conditions. We include Minority Immigration as a way of separating the effect of immigration from net internal migration, the latter being represented by Minority Net Migration. This has the advantage of 
enabling us to determine whether high levels of net internal migration of minority populations also adversely affect changes in joblessness and wages between 1980 (1979) and 1990 (1989).

Minority Net Migration and Minority Immigration are global flow measures, since they are not specific with respect to the age, labor force status, and/or industry of employment for the reference population. Thus, it may be that these measures capture the general effect of migration on the local economy, resulting in a decline in joblessness and an increase in wages, because of increased demand for goods and services. To minimize this possibility, we include White Population Change to capture the effect of increased local aggregate demand (see description of control variables below). We claim that an increase in the non-Hispanic white population of metropolitan areas is an indicator of an expanding or booming local economy with expanding job opportunities which would tend attract to native workers, resulting in lower joblessness and higher wages. This hypothesis complements that advanced by Frey (1995) and Walker, Ellis, and Barff (1992), who suggest that native white and black workers are being pushed out of places with high immigration flows. We expect White Population Change to be beneficial for whites, less so for blacks, Asians, and Hispanics, and possibly negative for immigrants.

Foreign-Born Share and Change in Foreign-Born Share are industry sector specific and thus can be used to assess whether the concentration of immigrants (and/or changes therein) increases joblessness and/or lowers wages for workers in a major industry sector. Although it is generally acknowledged that competition between natives and immigrants, and the subsequent displacement of the former by the latter, cannot occur unless members of the two groups work in a similar industry sector and occupation, few efforts have been made to assess the effect of immigrant concentrations in this manner (see Altonji and Card, 1991; Bailey and Waldinger, 1991a). If immigrants displace native workers because they are in a weaker bargaining position, then we would expect joblessness and wages to be much lower among immigrants than native workers in those industry sectors in which they are highly concentrated and/or in which their percentage of the workforce is increasing. 
$\underline{\text { Control Variables. }}$ Our model includes control variables to take account of structural factors associated with labor demand conditions prevailing in local labor markets, including White Population Change (1980-88); 1980-90 changes in the White Unemployment Rate, Mean Household Income, Proportion of the Metropolitan Labor Force Employed in an Industry Sector, ${ }^{7}$ and Metropolitan Population Size. We include these variables to control for intermetropolitan variations in labor demand conditions. Ethnic minorities may experience rising joblessness and/or declining wages because of changes in labor demand conditions not directly related to migration. ${ }^{8}$ We treat white population change as an indicator of general economic trends occurring in a labor market. In doing so, we are assuming that white population change is likely to be very responsive to local economic change, and therefore is a useful barometer of that change. In addition, we are concerned that changes in the white unemployment rate may not fully capture the differential impact of local economic change on workers of the different ethnic groups. Note that the association of white population change, unlike the other control variables, is specific to the individual ethnic groups. We do this to make allowances for the differential impact of economic growth on the labor market outcome of individual ethnic groups.

In the case of labor supply conditions, we use two control variables as proxies, Minority Share of the Total Metropolitan Population in 1980 and Ethnic Composition of a Metropolitan Area in 1980. The latter variable was obtained by classifying metropolitan areas based on the presence of 1,000 or more respondents over 18 years old for one or more ethnic minority populations. Twenty metropolitan areas are predominantly non-Hispanic black and white in ethnic composition; 17 others are multiethnic, with all four groups present in significant numbers (the omitted category in Equation 1); ten consist of Hispanics, blacks, and whites; four of Hispanic and whites; and one of Asian, Hispanics, and whites. ${ }^{9,10}$ We estimated the following equation using 1980-90 change in the predicted probability of joblessness and hourly wages as dependent variables:

$\Delta \operatorname{JOBLESS}_{(90-80)}=\alpha+\Sigma \beta_{\mathrm{i}} \mathrm{V}_{\mathrm{j}}+\Sigma \beta_{\mathrm{i}} \mathrm{W}_{\mathrm{k}}+\Sigma \beta_{\mathrm{i}} \mathrm{X}_{\mathrm{l}}+\Sigma \beta_{\mathrm{i}} \mathrm{Z}_{\mathrm{m}}+\Sigma \beta_{\mathrm{i}} \mathrm{V}_{\mathrm{j}} \mathrm{W}_{\mathrm{k}}+\mathrm{e}$ 
where $\mathbf{A} \mathbf{J O B L E S S}_{(\mathbf{9 0 - 8 0})}$ is $1980-90$ change in the mean predicted probability of joblessness, specific to ethnicity, occupation, industrial sector, and metropolitan area. Equation 1 is also estimated for $\Delta \mathrm{WAGE}_{(89-79)}$, which is $1979-89$ change in mean predicted log of hourly wages, also specific to ethnicity, occupation, industry sector, and metropolitan area. $\mathbf{V}$ is a vector of five dummy variables representing ethnic/immigrant group status, including African American, Asian, Hispanic, and recent and long-term immigrant residents (non-Hispanic white is the omitted category); $\mathbf{W}$ is a vector of migration and growth characteristics of metropolitan areas, including immigration, internal migration, change in the size of the white population, and nativity composition of the labor force of an industry; $\mathbf{X}$ is a vector of the characteristics of workers, including gender (male), and skill level—professional/managers for whitecollar workers or craft/precision occupations for blue-collar workers; $\mathbf{Z}$ is a vector describing the labor market characteristics of metropolitan areas, including 1980 population, share of population minority in 1980, ethnic composition of metropolitan area, and changes in industrial composition, household income, and white unemployment; and VW is a vector of cross-product terms for the interaction of ethnic group status with the migration variables. All metric variables are expressed in log form. Definitions of all variables are reported in Appendix Table 1, and the means and standard deviations of all variables are reported in Appendix Table 2. Equation 1 is separately estimated for two broad occupational categories: white-collar workers $(\mathrm{N}=1,200)$ and blue-collar workers $(\mathrm{N}=1,436)$.

Major occupation is used as a stratifying variable because it corresponds closely to the kind of work activity in which individuals are actually involved in the labor market. This provides a means for determining the potential for competition, displacement, or substitution between native and immigrant workers in different occupational categories. We also stratify respondents into three exclusive and exhaustive industry sector categories, including (1) primary industries—construction and manufacturing; (2) secondary industries - transportation, utilities, wholesale and retail trade, entertainment, and personal services; and (3) tertiary industries-finance, insurance, real estate, business services, professional 
services, and public administration. This three-sector classification is crude, but unfortunately we could not provide more industry detail without reducing the number of ethnic groups and/or occupational categories employed in the analysis. We use industry as a stratifying variable because previous research indicates substantial variation in the concentration of ethnic populations across industrial sectors, reflecting differences in skills, experiences, self-employment patterns and social-network-sustained niches (see Altonji and Card, 1991; Waldinger, 1994; Logan, Alba, and McNulty, 1994). Native workers' competition with and displacement by immigrant workers are less likely to occur in the absence of both groups working in the same industrial sector (Bailey and Waldinger, 1991a).

The cross-product terms (VW) involving the interaction of ethnic group status with the migration variables provide tests of whether the association of the latter with 1980-90 changes in the predicted probability of joblessness and hourly wages differs for native African Americans, Hispanics, Asians, and two immigrant groups relative to non-Hispanic whites. If migration differentially affects the labor market status of native workers based on group affiliation, this should be reflected in the pattern of variation exhibited by the shift coefficients for the cross-product terms. Thus, Equation 1 relates 1980-90 changes in the predicted probability of joblessness and 1979-89 changes in predicted hourly wages for native and immigrant workers to the flow of internal and international migration to a metropolitan area, as well as the share and change in share of a local industry sector's work force that is foreign born. As noted previously, young low-skilled native workers are substantially more likely to be adversely affected by the presence of immigrant workers than are native workers in other occupations requiring one or more years of postsecondary education. In most low-skilled jobs for which immigrants are qualified, the amount of training and experience required is often very low, and workers need not speak English fluently. Also, employers are receptive to workers who are perceived as having relatively low reservation wages. Given low wages, no fringes, and poor working conditions, labor turnover rates are likely to be high, and there is also a good chance that the share of immigrants who are undocumented will also be high. In addition, 
as others have noted, the demand for low-skilled workers has been declining because of economic restructuring (see Kasarda, 1985; Levy, 1987; Harrison and Bluestone, 1988), resulting in increased competition, reduced employment opportunities, and low wages. If immigrants become the preferred workers for a given occupation within an industrial sector, one would expect their wages to be slightly lower than those of native workers, but their employment levels to be appreciably higher than native workers.

In applying Equation 1 to 1980-90 changes in the predicted probability of joblessness and 1979-89 changes in predicted hourly wages, we use the reciprocal of the square root of the sum of the variances of mean predicted values as weights. ${ }^{11}$ This procedure corrects for heteroskedasticity due to the predicted mean values for each metropolitan area/industry combination not having the same variance. Thus, Equation 1 attempts to explain industry and metropolitan area variations in changes in the log odds of joblessness and changes in log hourly earnings for whites, blacks, Hispanics, and Asian natives, and two categories of immigrants: those who have been in the U.S. less than 11 years versus those who have been in the United States 11 or more years.

\section{RESULTS}

Tables 1 and 2 report the general patterns of variation in the dependent variables, predicted probability of joblessness, and hourly wages for six ethnic/immigrant groups by gender and year. The mean probability of joblessness reported in Table 1 indicates that native blacks had the highest level joblessness, followed by Hispanics. Among men, native blacks had the highest probability of joblessness in both 1980 and 1990 and experienced the largest increase in joblessness during the 1980-90 decade. Only native whites experienced a decline in joblessness over the 1980-90 period, but the probability of joblessness for this group was not the lowest for each period-native Asians had the lowest level of 


\section{TABLE 1}

Mean Predicted Probability of Joblessness by Ethnicity and Gender: 1980 and $1990^{\mathrm{a}}$

\begin{tabular}{|c|c|c|c|c|c|}
\hline \multirow[b]{3}{*}{ Ethnicity by Gender } & \multicolumn{4}{|c|}{ Predicted Probability of Joblessness } & \multirow{3}{*}{$\begin{array}{c}\text { Ratio }(1990 / 1980) \\
\text { Mean Predicted } \\
\text { Probability }\end{array}$} \\
\hline & \multicolumn{2}{|c|}{1980} & \multicolumn{2}{|c|}{1990} & \\
\hline & Mean & Std. Dev. & Mean & Std. Dev. & \\
\hline \multicolumn{6}{|l|}{ Men } \\
\hline Non-Hispanic white & .139 & .067 & .124 & .039 & .892 \\
\hline Non-Hispanic black & .169 & .098 & .182 & .067 & 1.077 \\
\hline Hispanic & .145 & .065 & .151 & .047 & 1.041 \\
\hline Asian & .105 & .049 & .112 & .039 & 1.067 \\
\hline Immigrant $<11 \mathrm{yrs}$ & .130 & .055 & .130 & .037 & 1.000 \\
\hline Immigrant $>10$ yrs & .121 & .066 & .126 & .043 & 1.041 \\
\hline \multicolumn{6}{|l|}{ Women } \\
\hline Non-Hispanic white & .200 & .076 & .186 & .060 & .930 \\
\hline Non-Hispanic black & .221 & .106 & .239 & .097 & 1.081 \\
\hline Hispanic & .220 & .084 & .216 & .069 & .982 \\
\hline Asian & .163 & .057 & .176 & .061 & 1.080 \\
\hline Immigrant $<11 \mathrm{yrs}$ & .221 & .070 & .216 & .054 & .977 \\
\hline Immigrant $>10 y r s$ & .181 & .076 & .194 & .063 & 1.072 \\
\hline
\end{tabular}

${ }^{a}$ Values based on coefficients obtained from the estimations of Equation 1a ( $\left.\triangle \mathrm{JOBLESS}\right)$ for respondents 19-34 years old, not in school, not married, not disabled, and with 12 years of schooling or less. 
joblessness. Among women, blacks had the highest probability of joblessness only in 1990, in part because their level of joblessness increased while that of several of the other groups decreased.

Table 2 reports mean hourly wages for the various groups by gender and year. As expected, native whites and Asians had the highest hourly wages, while recent immigrants had the lowest wages. There are only slight differences in the hourly wages of blacks, Hispanics, and long-term immigrants. As suggested by previous studies, the hourly wages of men declined, ranging from 15 percent for recent immigrants to 6 percent for Asians. The hourly wages of women, except Asians, also declined, but the range is narrower, from 8 percent for blacks to 3 percent for Hispanics.

The picture emerging from Tables 1 and 2 is that Asians and whites are, on average, the most advantaged groups, and blacks, Hispanics, and recent immigrant groups are the least advantaged with respect to joblessness and wages. A logical next question is whether the relative fortunes of these groups are linked through structure and changes in labor market conditions of local areas. Do internal migrants and immigrants form a substitute labor supply, and did they, as major sources of change in the labor supply of local areas, contribute to the high relative level of joblessness observed for blacks and Hispanics in 1990? Did they contribute to the decline in the hourly wages of all groups between 1980 and 1990? To address these questions, we turn to the results obtained from estimating Equation 1 through weighted least squares analysis. (We do not report the zero-order correlations between explanatory and control variables, but simply note that most were less than $.40 .{ }^{12}$ ) The results are reported in Tables 3 and 4 .

Table 3 reports the association of selected variables with intermetropolitan variation in 1980-90 changes in joblessness for two broad occupational categories. For simplicity, we will not refer to dates in much of this text; the reader should refer to the tables for specific dates covered by these results. Model I of Table 3 assesses the general association of changes in the probability of joblessness with migration, white population change (an indicator of general economic change), and foreign-born share, controlling 
TABLE 2

Mean Predicted Hourly Wages by Ethnicity and Gender: 1980 and $1990^{\mathrm{a}}$

\begin{tabular}{|c|c|c|c|c|c|}
\hline \multirow[b]{3}{*}{ Ethnicity by Gender } & \multicolumn{4}{|c|}{ Predicted Hourly Wages } & \multirow{3}{*}{$\begin{array}{c}\text { Ratio }(1990 / 1980) \\
\text { Mean Hourly } \\
\text { Wages } \\
\end{array}$} \\
\hline & \multicolumn{2}{|c|}{1980} & \multicolumn{2}{|c|}{1990} & \\
\hline & Mean & Std. Dev. & Mean & Std. Dev. & \\
\hline \multicolumn{6}{|l|}{ Men } \\
\hline Non-Hispanic white & $\$ 9.19$ & 1.64 & $\$ 8.13$ & 1.79 & .885 \\
\hline Non-Hispanic black & 8.30 & 1.66 & 7.20 & 1.54 & .868 \\
\hline Hispanic & 7.97 & 1.50 & 7.17 & 1.64 & .900 \\
\hline Asian & 8.98 & 1.69 & 8.48 & 1.69 & .944 \\
\hline Immigrant<11yrs & 6.86 & 1.31 & 5.83 & 1.15 & .850 \\
\hline Immigrant $>10 \mathrm{yrs}$ & 8.27 & 1.71 & 7.33 & 1.65 & .886 \\
\hline \multicolumn{6}{|l|}{ Women } \\
\hline Non-Hispanic white & 6.23 & 1.15 & 5.96 & 1.45 & .957 \\
\hline Non-Hispanic black & 5.99 & 1.18 & 5.53 & 1.29 & .923 \\
\hline Hispanic & 5.66 & 1.03 & 5.50 & 1.30 & .972 \\
\hline Asian & 6.09 & 1.12 & 6.39 & 1.34 & 1.050 \\
\hline Immigrant $<11$ yrs & 4.95 & 1.03 & 4.58 & 1.03 & .925 \\
\hline Immigrant $>10 y r s$ & 6.02 & 1.25 & 5.64 & 1.34 & .937 \\
\hline
\end{tabular}

${ }^{\mathrm{a}}$ Values based on coefficients obtained from the estimation of Equation $1 \mathrm{~b}(\Delta \mathrm{WAGE})$ for respondents 19-34 years old, not in school, not married, not disabled, and with 12 years of schooling or less. 
TABLE 3

Determinants of Intermetropolitan Variation in 1980-90 Changes in the Predicted Probability of Joblessness

\begin{tabular}{|c|c|c|c|c|c|c|c|c|}
\hline \multirow[b]{3}{*}{ Variables } & \multicolumn{4}{|c|}{ Model I } & \multicolumn{4}{|c|}{ Model II } \\
\hline & \multicolumn{2}{|c|}{ White-Collar } & \multicolumn{2}{|c|}{ Blue-Collar } & \multicolumn{2}{|c|}{ White-Collar } & \multicolumn{2}{|c|}{ Blue-Collar } \\
\hline & Coefficient & S. E. & Coefficient & S. E. & Coefficient & S. E. & Coefficient & S.E. \\
\hline Intercept & $10.699 * * *$ & 1.104 & -.437 & 1.763 & $8.324 * * *$ & 1.458 & -.302 & 2.840 \\
\hline Male & $.170 * * *$ & .010 & $.084 * * *$ & .031 & $.164 * * *$ & .015 & $.083 * * *$ & .031 \\
\hline \multicolumn{9}{|l|}{ Ethnic/Immigrant Group } \\
\hline Non-Hispanic white & $-^{\mathrm{a}}$ & - & $-^{\mathrm{a}}$ & - & $-^{\mathrm{a}}$ & - & $-^{\mathrm{a}}$ & - \\
\hline Non-Hispanic black & $.052 * *$ & .022 & -.017 & .031 & .585 & 1.557 & -3.122 & 3.423 \\
\hline Hispanic & $.040 *$ & .024 & -.000 . & .034 & 1.358 & 1.732 & 4.262 & 3.638 \\
\hline Asian & .039 & .030 & .003 & .045 & 2.019 & 1.852 & .407 & 3.534 \\
\hline Immigrant $<11 \mathrm{yrs}$ & .016 & .022 & .007 & .029 & 2.105 & 1.659 & -3.149 & 3.014 \\
\hline Immigrant $>10 y r s$ & .021 & .022 & .020 & .029 & 2.342 & 1.819 & -2.317 & 2.942 \\
\hline White Population Change, $1980-88$ & -.056 & .074 & -.206 & .132 & .016 & .127 & -.014 & .165 \\
\hline Net Minority Migration, $1980-88$ & $.795 * * *$ & .101 & .201 & .178 & $.813 * * *$ & .147 & -.045 & .294 \\
\hline Minority Immigration, $1980-88$ & $-1.478 * * *$ & .128 & -.105 & .206 & $-1.314 * * *$ & .135 & .055 & .217 \\
\hline \multicolumn{9}{|l|}{ Share of Industry's Labor Force } \\
\hline Foreign Born, 1980 & -.019 & .016 & -.029 & .025 & $.060 * * *$ & .023 & -.008 & .041 \\
\hline \multicolumn{9}{|l|}{ Ratio (1990/1980) Share of Industry's } \\
\hline Labor Force Foreign Born & -.018 & .038 & $.402 * * *$ & .061 & $.141 * *$ & .061 & $.236 * *$ & .103 \\
\hline Population Size, 1980 & $-1.333 * * *$ & .118 & -.075 & .190 & $-1.180^{* * *}$ & .125 & .087 & .197 \\
\hline Percent Minority Population, 1980 & $-1.266^{* * *}$ & .123 & -.130 & .202 & $-1.117 * * *$ & .130 & .027 & .209 \\
\hline
\end{tabular}


TABLE 3, continued

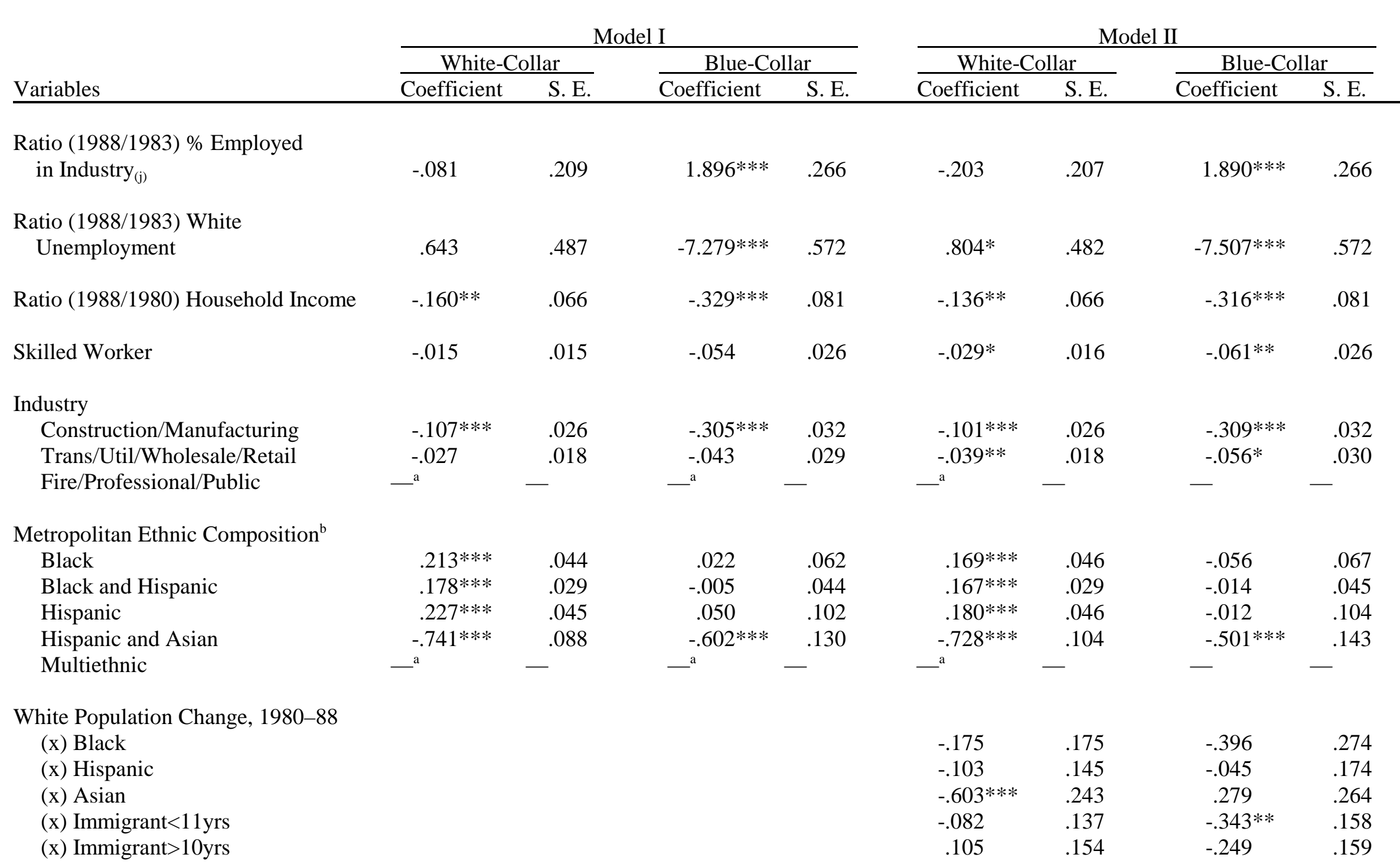


TABLE 3, continued

\begin{tabular}{|c|c|c|c|c|c|c|c|c|}
\hline \multirow[b]{3}{*}{ Variables } & \multicolumn{4}{|c|}{ Model I } & \multicolumn{4}{|c|}{ Model II } \\
\hline & \multicolumn{2}{|c|}{ White-Collar } & \multicolumn{2}{|c|}{ Blue-Collar } & \multicolumn{2}{|c|}{ White-Collar } & \multicolumn{2}{|c|}{ Blue-Collar } \\
\hline & Coefficient & S. E. & Coefficient & S. E. & Coefficient & S. E. & Coefficient & S. E. \\
\hline
\end{tabular}

Net Minority Migration, 1980-88
(x) Black
(x) Hispanic
(x) Asian
(x) Immigrant $<11$ yrs
(x) Immigrant $>10 y r s$

Minority Immigration, 1980-88
(x) Black
(x) Hispanic
(x) Asian
(x) Immigrant $<11$ yrs
(x) Immigrant $>10 y r s$

Share of Industry's Labor Force Foreign Born, 1980
(x) Black
(x) Hispanic
(x) Asian
(x) Immigrant $<11$ yrs
(x) Immigrant $>10 y r s$

Ratio (1990/1980) Share of Industry's Labor Force Foreign Born
(x) Black
(x) Hispanic
(x) Asian
(x) Immigrant $<11$ yrs
(x) Immigrant $>10 y r s$

$\begin{array}{llll}-.032 & .169 & .320 & .371 \\ -.139 & .189 & -.502 & .397 \\ -.193 & .204 & -.082 & .390 \\ -.212 & .179 & .342 & .325 \\ -.226 & .197 & .258 & .317\end{array}$

$\begin{array}{llll}-.026 & .029 & .077 * & .044 \\ .035 & .035 & -.069 & .057 \\ -.117 * * & .053 & -.032 & .087 \\ .035 & .028 & .013 & .044 \\ .010 & .028 & .005 & .044\end{array}$

$\begin{array}{llll}-.108 * * * & .032 & -.012 & .051 \\ -.007 & .042 & .130 * * & .064 \\ -.167 * * * & .066 & -.005 & .089 \\ -.019 & .026 & -.102 * * & .048 \\ -.307 * * * & .081 & -.119 * * * & .048\end{array}$

$\begin{array}{llll}-.121 & .081 & .032 & .133 \\ -.154 & .142 & .412 * * & .194 \\ .216 & .154 & .770 * * * & .242 \\ -.307 * * * & .081 & -.198 * & .120 \\ -.270 * * * & .081 & .238 * * & .122\end{array}$

(table continues) 
TABLE 3, continued

\begin{tabular}{|c|c|c|c|c|c|c|c|c|}
\hline \multirow[b]{3}{*}{ Variables } & \multicolumn{4}{|c|}{ Model I } & \multicolumn{4}{|c|}{ Model II } \\
\hline & \multicolumn{2}{|c|}{ White-Collar } & \multicolumn{2}{|c|}{ Blue-Collar } & \multicolumn{2}{|c|}{ White-Collar } & \multicolumn{2}{|c|}{ Blue-Collar } \\
\hline & Coefficient & S. E. & Coefficient & S. E. & Coefficient & S.E. & Coefficient & S.E \\
\hline $\mathrm{R}^{2}$ corrected & .330 & & .278 & & .353 & & .287 & \\
\hline Observations & \multicolumn{2}{|c|}{1,200} & \multicolumn{2}{|c|}{1,436} & \multicolumn{2}{|c|}{1,200} & \multicolumn{2}{|c|}{1,436} \\
\hline
\end{tabular}

$* \mathrm{p}<.10 ; * * \mathrm{p}<.05 ; * * * \mathrm{p}<.01$

${ }^{a}$ Omitted category

${ }^{\mathrm{b}}$ Whites and immigrants are included in all metropolitan areas. 
general supply and demand conditions in local labor markets. Model II, on the other hand, also includes terms for the interaction of ethnic/immigrant group membership with internal migration, immigration, white population change, and foreign-born share. This model assesses whether migration and industrial concentration of foreign-born workers differentially affect changes in the probability of joblessness among native blacks, whites, Asians, and Hispanics, and the two immigrant groups. The discussion of results focuses primarily on the effects of net migration, immigration, white population change, and foreign-born share.

Model I of Table 3 indicates that minority net migration (internal migration) is associated with increased joblessness, while minority immigration is associated with decreased joblessness for whitecollar workers. The results suggest that internal migration might possibly lead to slack labor conditions, while immigration might possibly be complementary to the employment of white-collar workers. Among blue-collar workers, net migration and immigration are not associated with the probability of joblessness. Decade change in the white population, foreign-born share, and change in that share are not associated with 1980-90 change in the probability of joblessness for white-collar workers, but an increase in foreign-born share is positively associated with increased joblessness for blue-collar workers.

The association of change in joblessness with net migration and immigration reported under Model II, which includes the interaction terms, is only sightly different from that reported under Model I. Change in joblessness is still positively associated with net migration and negatively associated with immigration for white-collar workers. These associations apply equally to the individual ethnic groups, with two exceptions. First, the decrease in the probability of joblessness associated with immigration for Asian white-collar workers is even greater $[-1.314$ versus $(-1.314(+)-.117=-1.431)]$. Second, for black blue-collar workers, an increase in the probability of joblessness is now marginally associated with immigration $[.055(\mathrm{NS})+.077=.077]$. 
The inclusion of the interaction terms in Model II dramatically changes the association of foreign-born share (and changes therein) with change in joblessness. Both foreign-born share and changes in share are now positively associated with increased joblessness for white-collar workers; the association of changes in foreign-born share is substantially reduced for blue-collar workers, although the coefficient is still statistically significant. More important, adding the baseline and interaction (or net shift) coefficients for these variables, the overall net effect of foreign-born share and changes in share differs appreciably for the individual ethnic/immigrant groups. Specifically, the association of foreignborn share with increased joblessness is negative for black $(.060+(-1.08)=-.048)$, Asian $(-.107)$, and long-term immigrant $(-.247)$ white-collar workers, while the association for Hispanics, recent immigrants, and whites remains positive. For blue-collar workers, increased joblessness is also negatively associated with foreign-born share for recent and long-term immigrants, but positively associated for Hispanics.

In the case of change in foreign-born share, the probability of joblessness increased for all native white-collar workers but decreased for the two immigrant groups. Among blue-collar workers, joblessness increased for all workers, particularly for Hispanics, Asians, and long-term immigrants. However, the increase for recent immigrants was substantially smaller $(.236+(-.198)=.038)$. In sum, these results are consistent with the point of view that native workers in industries increasingly dominated by foreign-born workers experience higher levels of joblessness. Whether in fact the increased presence of immigrants is at least partly responsible for the increase in joblessness among native workers between 1980 and 1990 remains an open question. As discussed below, several other interpretations of these results are possible.

Model I of Table 4, as Model I of Table 3, assesses the general association of 1980-90 change in predicted hourly wages with migration, 1980-88 change in the white population, and foreign-born share of an industry's workforce, controlling for general labor supply and demand conditions. Changes in the 
TABLE 4

Determinants of Intermetropolitan Variation in 1980-90 Changes in Predicted Hourly Wages

\begin{tabular}{|c|c|c|c|c|c|c|c|c|}
\hline \multirow[b]{3}{*}{ Variables } & \multicolumn{4}{|c|}{ Model I } & \multicolumn{4}{|c|}{ Model II } \\
\hline & \multicolumn{2}{|c|}{ White-Collar } & \multicolumn{2}{|c|}{ Blue-Collar } & \multicolumn{2}{|c|}{ White-Collar } & \multicolumn{2}{|c|}{ Blue-Collar } \\
\hline & Coefficient & S. E. & Coefficient & S. E. & Coefficient & S. E. & Coefficient & S.E. \\
\hline Intercept & $.910 * * *$ & .267 & $-1.653 * * *$ & .289 & $.764 * *$ & .368 & $-2.026 * * *$ & .472 \\
\hline Male & $-.018 * * *$ & .004 & $-.024 * * *$ & .004 & $-.017 * * *$ & .004 & $-.024 * * *$ & .004 \\
\hline \multicolumn{9}{|l|}{ Ethnic/Immigrant Group } \\
\hline Non-Hispanic black & .000 & .005 & .006 & .005 & .071 & .400 & .615 & .536 \\
\hline Hispanic & .004 & .006 & .003 & .006 & -.332 & .456 & .730 & .577 \\
\hline Asian & .000 & .007 & .005 & .007 & .583 & .463 & $1.061^{*}$ & .587 \\
\hline Immigrant $<11 \mathrm{yrs}$ & -.001 & .005 & -.002 & .005 & .205 & .426 & .450 & .519 \\
\hline Immigrant $>10 y r s$ & -.002 & .005 & -.005 & .005 & .428 & .420 & -.121 & .509 \\
\hline White Population Change, 1980-88 & .004 & .017 & $.034 * *$ & .016 & .045 & .031 & .020 & .032 \\
\hline Net Minority Migration, 1980-88 & $.193 * * *$ & .024 & $-.083 * * *$ & .029 & $.207 * * *$ & .037 & -.039 & .049 \\
\hline Minority Immigration, 1980-88 & $-.230 * * *$ & .031 & $.162 * * *$ & .034 & $-.231 * * *$ & .032 & $.166^{*}$ & .035 \\
\hline \multicolumn{9}{|l|}{ Share of Industry's Labor Force } \\
\hline Foreign Born, 1980 & -.001 & .004 & $.049 * * *$ & .004 & .002 & .006 & $.049 * * *$ & .007 \\
\hline \multicolumn{9}{|l|}{ Ratio (1990/1980) Share of Industry's } \\
\hline Labor Force Foreign Born & -.015 & .008 & $.116^{* * *}$ & .010 & .013 & .014 & $.094 * * *$ & .018 \\
\hline Population Size, 1980 & $-.184 * * *$ & .028 & $.0163 * * *$ & .031 & $-.183 * * *$ & .030 & $.159 * * *$ & .032 \\
\hline Percentage Minority Population, 1980 & $-.246 * * *$ & .029 & $.146 * * *$ & .033 & $-.247 * * *$ & .031 & $.148 * * *$ & .034 \\
\hline
\end{tabular}

(table continues) 
TABLE 4, continued

\begin{tabular}{|c|c|c|c|c|c|c|c|c|}
\hline \multirow[b]{3}{*}{ Variables } & \multicolumn{4}{|c|}{ Model I } & \multicolumn{4}{|c|}{ Model II } \\
\hline & \multicolumn{2}{|c|}{ White Collar } & \multicolumn{2}{|c|}{ Blue Collar } & \multicolumn{2}{|c|}{ White Collar } & \multicolumn{2}{|c|}{ Blue Collar } \\
\hline & Coefficient & S. E. & Coefficient & S. E. & Coefficient & S. E. & Coefficient & S.E. \\
\hline \multicolumn{9}{|l|}{ Ratio (1988/1983) Percent } \\
\hline Employed in Industry $_{(\mathfrak{j})}$ & -.023 & .052 & -.032 & .048 & -.034 & .052 & -.022 & .048 \\
\hline Ratio (1988/1983) White Unemployment & $.600 * * *$ & .115 & $.449 * * *$ & .111 & $.560 * * *$ & .113 & $.447 * * *$ & .111 \\
\hline Ratio (1988/1980) Household Income & $.038 * * *$ & .015 & $-.051 * * *$ & .015 & $.035 * *$ & .015 & $-.059 * * *$ & .015 \\
\hline Skilled Worker & $.010 * * *$ & .004 & $.025 * * *$ & .004 & $.009 * *$ & .004 & $.024 * * *$ & .004 \\
\hline \multicolumn{9}{|l|}{ Industry } \\
\hline Construction/Manufacturing & .006 & .006 & -.008 & .005 & .008 & .006 & -.008 & .005 \\
\hline Trans/Util/Wholesale/Retail & $-.020 * * *$ & .004 & -.007 & .005 & $-.022 * * *$ & .004 & $-.009 *$ & .005 \\
\hline Fire/Professional/Public & - & - & - & - & - & - & - & - \\
\hline \multicolumn{9}{|l|}{ Metropolitan Ethnic Composition ${ }^{\mathrm{b}}$} \\
\hline Black & $.038 * * *$ & .010 & $.067 * * *$ & .009 & $.038 * * *$ & .010 & $.061 * * *$ & .010 \\
\hline Black and Hispanic & $.045^{* * *}$ & .007 & $.075 * * *$ & .007 & $.044 * * *$ & .007 & $.069 * * *$ & .007 \\
\hline Hispanic & $.066 * * *$ & .010 & -.002 & .016 & $.069 * * *$ & .010 & -.008 & .017 \\
\hline Hispanic and Asian & .032 & .023 & $.110 * * *$ & .021 & $.051^{*}$ & .029 & $.109 * * *$ & .023 \\
\hline Multiethnic & $-^{\mathrm{a}}$ & - & $-^{\mathrm{a}}$ & - & $-^{\mathrm{a}}$ & - & - & - \\
\hline \multicolumn{9}{|l|}{ White Population Change, $1980-88$} \\
\hline (x) Black & & & & & -.061 & .043 & .021 & .032 \\
\hline (x) Hispanic & & & & & -.006 & .044 & .009 & .037 \\
\hline (x) Asian & & & & & .105 & .066 & -.036 & .053 \\
\hline (x) Immigrant $<11 \mathrm{yrs}$ & & & & & -.046 & .037 & .005 & .027 \\
\hline (x) Immigrant $>10 \mathrm{yrs}$ & & & & & -.036 & .037 & -.018 & .027 \\
\hline
\end{tabular}


TABLE 4, continued

\begin{tabular}{|c|c|c|c|c|c|c|c|c|}
\hline \multirow[b]{3}{*}{ Variables } & \multicolumn{4}{|c|}{ Model I } & \multicolumn{4}{|c|}{ Model II } \\
\hline & \multicolumn{2}{|c|}{ White Collar } & \multicolumn{2}{|c|}{ Blue Collar } & \multicolumn{2}{|c|}{ White Collar } & \multicolumn{2}{|c|}{ Blue Collar } \\
\hline & Coefficient & S. E. & Coefficient & S. E. & Coefficient & S. E. & $\overline{\text { Coefficient }}$ & S. E. \\
\hline \multicolumn{9}{|c|}{ Net Minority Migration, $1980-88$} \\
\hline (x) Black & & & & & -.007 & .043 & -.064 & .058 \\
\hline (x) Hispanic & & & & & .030 & .050 & -.077 & .063 \\
\hline (x) Asian & & & & & -.070 & .051 & -.112 & .064 \\
\hline (x) Immigrant $<11 \mathrm{yrs}$ & & & & & -.018 & .046 & -.051 & .056 \\
\hline (x) Immigrant $>10 \mathrm{yrs}$ & & & & & -.043 & .045 & .010 & .055 \\
\hline \multicolumn{9}{|c|}{ Minority Immigration, $1980-88$} \\
\hline (x) Black & & & & & .009 & .007 & -.011 & .007 \\
\hline (x) Hispanic & & & & & $.019 * *$ & .008 & $-.018 * *$ & .009 \\
\hline (x) Asian & & & & & $.025 * *$ & .013 & $-.040 * * *$ & .013 \\
\hline (x) Immigrant $<11 \mathrm{yrs}$ & & & & & -.007 & .007 & .003 & .008 \\
\hline (x) Immigrant> $>10 \mathrm{yrs}$ & & & & & -.007 & .007 & .007 & .008 \\
\hline \multicolumn{9}{|c|}{ Share of Industry's Labor Force Foreign Born, 1980} \\
\hline (x) Black & & & & & .002 & .007 & -.006 & .008 \\
\hline (x) Hispanic & & & & & .008 & .010 & -.011 & .011 \\
\hline (x) Asian & & & & & $.055 * * *$ & .015 & -.007 & .015 \\
\hline (x) Immigrant $<11 \mathrm{yrs}$ & & & & & $-.012 * *$ & .006 & .008 & .008 \\
\hline (x) Immigrant $>10 y r s$ & & & & & -.009 & .006 & -.002 & .008 \\
\hline \multicolumn{9}{|c|}{ Ratio (1990/1980) Share of Industry's Labor Force Foreign Born } \\
\hline (x) Black & & & & & $-.066 * * *$ & .019 & .002 & .023 \\
\hline (x) Hispanic & & & & & .050 & .034 & $.068 * *$ & .032 \\
\hline (x) Asian & & & & & $-.081 * *$ & .040 & .027 & .038 \\
\hline (x) Immigrant< $11 \mathrm{yrs}$ & & & & & -.029 & .019 & .015 & .022 \\
\hline (x) Immigrant $>10 y r s$ & & & & & -.030 & .019 & .024 & .022 \\
\hline
\end{tabular}

(table continues) 
TABLE 4, continued

\begin{tabular}{|c|c|c|c|c|c|c|c|c|}
\hline \multirow[b]{3}{*}{ Variables } & \multicolumn{4}{|c|}{ Model I } & \multicolumn{4}{|c|}{ Model II } \\
\hline & \multicolumn{2}{|c|}{ White Collar } & \multicolumn{2}{|c|}{ Blue Collar } & \multicolumn{2}{|c|}{ White Collar } & \multicolumn{2}{|c|}{ Blue Collar } \\
\hline & Coefficient & S.E. & Coefficient & S. E. & Coefficient & S. E. & Coefficient & S.E. \\
\hline $\mathrm{R}^{2}$ corrected & .329 & & .363 & & .353 & & .369 & \\
\hline Observations & \multicolumn{2}{|c|}{1,200} & \multicolumn{2}{|c|}{1,436} & \multicolumn{2}{|c|}{1,200} & \multicolumn{2}{|c|}{1,436} \\
\hline
\end{tabular}

$* \mathrm{p}<.10 ; * * \mathrm{p}<.05 ; * * * \mathrm{p}<.01$

${ }^{\mathrm{a} O m i t t e d ~ c a t e g o r y ~}$

${ }^{b}$ Whites and immigrants are included in all metropolitan areas. 
white population of metropolitan areas are not associated with changes in hourly wages for white-collar workers, but are positively associated with changes in wages for blue-collar workers. Both internal migration and international immigration of minority individuals are statistically associated with changes in hourly wages. In the case of white-collar workers, the association is positive for internal migration but negative for immigration. In contrast, these associations are the reverse for blue-collar workers; that is, higher internal migration is inversely associated with changes in hourly wages, and immigration is positively associated with changes in hourly wages.

Looking at the results for Model II, which includes the interaction terms, we note that the positive association of changes in hourly wages with internal migration and the negative association with immigration apply to all native and immigrant white-collar workers, although the negative association of changes in wages with immigration is smaller for native Hispanics and Asians. For blue-collar workers, the negative association between changes in wages and internal migration disappears with the addition of the interaction terms, which suggests that the general association was mainly compositional in character. On the other hand, the positive association of changes in wages with immigration applies to all the native and immigrant blue-collar workers, except, as with white-collar workers, the association is marginally weaker for Hispanics and Asians.

The contrasting changes in wage responses may reflect differences in labor market conditions faced by white-collar and blue-collar workers and possibly contrasts in the complementary nature of labor demand for these two categories of workers. That internal migrants appear to expand opportunities for low-level administrative and nonprotective service workers is consistent with previous work indicating the complementary character of migration flows to white-collar workers in general (see Smith and Edmonston, 1997; Espenshade, forthcoming). In the case of immigration, the influence appears to operate in the opposite direction, although this does not seem plausible. An alternative explanation could be that low-skilled immigrant workers are absorbed into the low-wage service sector primarily associated 
with ethnic economies, such that lower wages in that sector are not a consequence of increased labor supply but rather reflect the expansion of the low-wage sector. The positive association of immigration with increased hourly wages of low-skilled blue-collar workers reported in Table 4 might possibly be the result of applying appropriate statistical controls. Obviously, additional research is needed to further evaluate this claim.

Foreign-born share and change in that share are not in general associated with changes in hourly wages for white-collar workers. However, a statistically significant, but marginal, association exists for several of the groups. The association of changes in hourly wages with the foreign-born share is positive for Asians but negative for recent immigrants; the association of changes in hourly wages with changes in the foreign-born share is negative for blacks and Asians. Among blue-collar workers, changes in hourly wages are positively associated with both foreign-born share and change in that share. These associations apply to all groups, and they are the opposite of what one would expect if immigrant and native noncollege-educated blue-collar workers are substitutes.

\section{DISCUSSION}

\section{$\underline{\text { Summary of Findings }}$}

We began this investigation seeking answers to two questions: (1) Did internal and/or international migration contribute to the increased joblessness observed for blacks, Hispanics, and Asians, particularly for men? (2) Did migration contribute to the decline in the hourly wages of both native and foreign-born workers during the 1980s? The answers to these questions, based on the results reported in the previous section, depend on the occupational category, the ethnic/immigrant group, and whether the reference variable is immigration, internal migration, or the foreign-born composition of an industry's workforce. Our decision to focus on noncollege-educated young wage and salary workers was premised on the assumption that given the declining demand for these workers, the labor market 
circumstances of these workers are more likely to be adversely affected by immigration. However, there is some evidence to support the claim that the migrant labor supply is a substitute for native workers. The results can be summarized as follows.

First, consistent with expectations, 1980-90 changes in joblessness are positively associated with internal migration, but negatively associated with immigration flows, for white-collar workers; positively but marginally associated with immigration for black blue-collar workers; and positively associated with changes in the foreign-born share for both white-collar and blue-collar workers. Second, consistent with expectations, 1979-89 changes in hourly wages are inversely associated with immigration for whitecollar workers, and also inversely associated with change in the foreign-born share for black and Asian white-collar workers. On the other hand, changes in hourly wages are positively associated with internal migration for white-collar workers, immigration for blue-collar workers, and changes in the foreign-born share for both white-collar and blue-collar workers.

Do these results support the claim of immigration flows contributing to the displacement of native workers? Based on reported results, we conclude that migration, particularly immigration, does not appear to have been a major factor associated with the substantial increases in joblessness and decreases in hourly wages experienced by native workers during the 1980s. Paradoxically, our results suggest that gross minority immigration flows reduced the level of joblessness of white-collar workers and did not contribute to the increased joblessness of native blue-collar workers, except for blacks. However, the marginal character of this association for black blue-collar workers suggests caution in interpreting it as evidence of a labor substitution effect. On the other hand, the effects of immigration on wages were the opposite of expectations-specifically, the wages of white-collar workers declined while those of bluecollar workers increased. 


\section{CONCLUSIONS}

The marginal and conflicting results reported for the association of immigration flows with changes in joblessness and wages are consistent with the results of previous work. These results are encouraging because the instrument used to measure immigration (and internal migration) was derived from a source other than the census-based PUMS or STF files. In addition, no study of which we are aware has included both internal migration and immigration in models evaluating the labor market status of native workers. Friedberg and Hunt (1995) may be correct in asserting that the adjustment of local labor markets to immigration may be very quick, particularly if the inflow is modest and the economy is sufficiently diversified to allow for the absorption of immigrants in a variety of sectors.

The search for immigration's impact has focused primarily on an assessment of the impact of undifferentiated flows to labor market areas or the representation of immigrants in the general labor market. It may well be that an undifferentiated migration flow measure may not be the appropriate instrument with which to assess the effect of immigration. For example, it is generally acknowledged that the displacement of native by immigrant workers generally occurs within industries (see Altonji and Card, 1991; Bailey and Waldinger, 1991a; Waldinger, 1994). Unfortunately, with the exception of a few case studies (just cited), we know of no other study that has attempted to link the increased presence of immigrants in specific industries to the labor market status of native workers. Results reported here on the association of changes in joblessness and wages with changes in the foreign-born composition of industrial sectors clearly suggest the latter as a more important source of change in the relative standing of native workers. Increased joblessness during the 1980s was substantially associated with the increased presence of foreign-born workers, whereas the level of joblessness experienced by foreign-born workers themselves either remained constant or declined. Although this appears to be clear evidence of substitution or displacement effects, other sources of change may have contributed to this outcome. For 
example, native workers may have voluntarily exited declining and low-wage industrial sectors in search of better opportunities. Our results cannot adjudicate between these competing hypotheses.

We find little evidence to support Borjas's (1998) conclusion that African Americans are more likely to suffer a greater net loss in economic well-being than members of other ethnic minority populations. Indeed, the effect of changes in foreign-born share on joblessness indicates that Hispanics and Asians are more disadvantaged than blacks. This should not be surprising, considering that both of these panethnic groups have high immigrant shares, possibly with immigrants and natives linked generationally.

We believe that much could be learned from further exploration of the impact of the cumulative concentration of the foreign born in selected industries, both as owners and as workers. We know little about the links between immigration flows and the increased concentration of immigrant workers in specific labor market sectors, except in a few case studies (see Waldinger, 1994, 1996a, b, for reviews). Findings from several studies indicate that immigrants are highly concentrated in specific industries and occupations, limiting the possibility of substitution (see Muller and Espenshade, 1985; Altonji and Card, 1991; Waldinger, 1996a; Scott, 1996; Light and Rosenstein, 1995; Smith and Edmonston, 1997). Indeed, immigrant workers may have priority access to jobs created by immigrant entrepreneurs in a segmented labor market, as for example, jobs in an ethnic economy.

We excluded the self-employed from the reported analysis, but it is clear that an assessment of the influence of immigration on labor market outcomes must consider all possible ways in which that influence can be transmitted. Immigrants who are successful in establishing businesses and able to employ other immigrants are not likely to generate the same kind of labor market dynamics as those who secure employment in industries in which members of their immigrant (ethnic) group historically have been underrepresented. 
Finally, we should note that the effort to take account of the nativity composition of industries was less than satisfactory, mainly because of the broadness of the industrial categories. A more refined industrial classification would yield different results. For example, given the broad industry and occupational classifications employed here, it is possible that the increased concentration of immigrants may be occurring in emerging employment sectors with no history of minority concentration (see Scott, 1996). 

Source: 1980, 1990 5\% PUMS

$\triangle \mathrm{WAGE}_{(89-79)}$

$\triangle$ JOBLESS $_{(90-80)}$

\section{Non-Hispanic Black \\ Non-Hispanic White \\ Hispanic \\ Asian \\ Immigrant $<11$}

Immigrant $>10$

Male

Skill

Primary

Secondary

Tertiary

Foreign Share

Foreign Share 1980-90 change in

AFROAM

AFROHISP

LATINO

HISPASA
1989-1979 change in mean predicted hourly wage.

1990-1980 change in the mean predicted probability of joblessness.

Is 1 if ethnic group is black; 0 otherwise.

Omitted category.

Is 1 if ethnic group is Hispanic; 0 otherwise.

Is 1 if ethnic group is Asian; 0 otherwise.

Is 1 if group consists of immigrants who have lived in U.S. less than 11 years; 0 otherwise.

Is 1 if group consists immigrants who have lived in U.S. for more than 10 years; 0 otherwise.

Is 1 if gender is male; 0 otherwise.

Is 1 if occupation is professional/managerial (white-collar) or craft/precision (blue-collar).

Is 1 if employment sector is construction or manufacturing; 0 otherwise.

Is 1 if employment sector is transportation, communication, utilities, wholesale, retail trade, personal services, or entertainment; 0 otherwise.

Omitted industry category.

Percentage of workers in an industry who are foreign born.

Ratio of 1990 to 1980 percentage of workers in an industry sector who are foreign born.

Is 1 if metropolitan area contains 1,000 or more black and white workers.

Is 1 if metropolitan area contains 1,000 or more black, Hispanic, and white workers.

Is 1 if metropolitan area contains 1,000 or more Hispanic and white workers.

Is 1 if metropolitan area contains 1,000 or more Asian, Hispanic, and white workers.

\section{4, 1987 Survey of Income and Program Participation (SIPP)}

RINDUST

White Unemploy. HH. Income
Ratio of 1988 to 1983 percentage of labor force in an industry sector.

Ratio of 1988 to 1983 white unemployment rate.

Ratio of 1988 to 1983 mean monthly household income.

(table continues) 
APPENDIX TABLE 1, continued

1989, 1990 Current Population Reports

Minority Migration

Minority Immigration

Population Size

Minority Population

White Population Change
Estimated net minority migrants to a metropolitan area, 1980-1988.

Estimated number of minority immigrants to a metropolitan area, 1980-90.

1980 metropolitan population.

Percentage of metropolitan population black, Hispanic, and Asian.

$1980-88$ change in the white population of a metropolitan area. 
APPENDIX TABLE 2

Mean and Standard Deviation of Variables ${ }^{\mathrm{a}}$

\begin{tabular}{|c|c|c|c|c|}
\hline \multirow[b]{2}{*}{ Variables } & \multicolumn{2}{|c|}{ White-Collar } & \multicolumn{2}{|c|}{ Blue-Collar } \\
\hline & Mean & S. D. & Mean & S. D. \\
\hline Male & .455 & 2.422 & .889 & 1.679 \\
\hline Skilled Worker & .453 & 2.422 & .735 & 2.360 \\
\hline \multicolumn{5}{|l|}{ Ethnic/Immigrant Group } \\
\hline Non-Hispanic black & .175 & 1.848 & .178 & 2.047 \\
\hline Hispanic & .183 & 1.652 & .129 & 1.792 \\
\hline Asian & .070 & 1.242 & .063 & 1.296 \\
\hline Immigrant $<11$ yrs & .198 & 1.937 & .226 & 2.237 \\
\hline Immigrant $>10 y r s$ & .187 & 1.896 & .222 & 2.222 \\
\hline White Population Change, $1980-88$ & -.134 & .800 & -.132 & 1.114 \\
\hline Net Minority Migration, $1980-88$ & 9.323 & .907 & 9.292 & .796 \\
\hline Minority Immigration, $1980-88$ & .949 & 5.204 & 1.192 & 5.220 \\
\hline \multicolumn{5}{|l|}{ Share of Industry's Labor Force } \\
\hline Foreign Born, 1980 & 1.958 & 4.496 & 1.677 & 4.329 \\
\hline \multicolumn{5}{|l|}{ Ratio (1990-1980) Share of Industry's } \\
\hline Labor Force Foreign Born & .402 & 1.260 & .41 & 1.342 \\
\hline Population Size, $1980(1,000 s)$ & 9.477 & 5.739 & 9.456 & 4.571 \\
\hline Percentage Minority Population, 1980 & 3.341 & 2.605 & .411 & 2.688 \\
\hline \multicolumn{5}{|l|}{ Ratio (1988/1983) \% Employed } \\
\hline in Industry $_{(\mathrm{j})}$ & .009 & .169 & -.0002 & .218 \\
\hline Ratio (1988/1983) White Unemployment & .027 & .077 & .025 & .106 \\
\hline \multicolumn{5}{|l|}{ Predicted 1980-90 Change in the } \\
\hline Mean Probability Joblessness & .090 & 1.363 & .117 & 2.151 \\
\hline \multicolumn{5}{|l|}{ Predicted 1979-89 Change in Mean } \\
\hline Hourly Wages & -.061 & .157 & -.061 & .180 \\
\hline Ratio (1988/1980) Household Income & -.154 & .623 & -.187 & .859 \\
\hline \multicolumn{5}{|l|}{ Industry } \\
\hline Primary & .156 & 1.765 & .205 & 2.159 \\
\hline Secondary & .328 & 2.284 & .190 & 2.100 \\
\hline \multicolumn{5}{|l|}{ Metropolitan Ethnic Composition ${ }^{\mathrm{b}}$} \\
\hline Black & .252 & 2.111 & .334 & 2.523 \\
\hline Black and Hispanic & .165 & 1.803 & .280 & 2.402 \\
\hline Hispanic & .120 & 1.580 & .014 & .624 \\
\hline Hispanic and Asian & .022 & .713 & .054 & 1.208 \\
\hline Number of observations - 52 & & & & \\
\hline
\end{tabular}

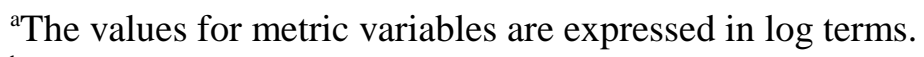

${ }^{\text {b}}$ Whites and immigrants are included in all metropolitan areas. 



\section{Endnotes}

${ }^{1}$ We have identified other problems as well. First, previous research has relied heavily on products from the decennial censuses, primarily because there are few available data files with detailed information about local labor market conditions that can be used to study the effects of immigration. The potential for estimating biased relationships is greater if all relevant variables are obtained from a common data source. In addition, the time periods covered by these data make it impossible to reconstruct a temporal ordering of relevant variables in ways that correspond to cause and effect relations. For example, earnings are reported for the previous year, while information on migration (both internal and international) covers the entire 5-year period up to the census week. Finally, few efforts have been made to ensure that the individual members of ethnic, gender, and nativity groups who are to be compared are similar with respect to relevant variables such as education, age, disability status, and marital status. If, for example, one wants to compare the wages of unskilled native black or Hispanic men or women with those of foreign-born men or women, but fails to control for attributes that determine wages at the individual level, it would be difficult to attribute a wage difference as being a positive or negative effect of immigration.

${ }^{2}$ The use of panethnic categories, especially for Asians and Hispanics, is less than satisfactory, since the residence and migration experiences of individual ethnic groups vary considerably. Unfortunately, focusing on individual ethnic groups, except Mexican Americans, would substantially reduce the number of metropolitan areas included in the analysis. Moreover, even if we restrict the analysis to blacks, Mexicans, and whites, we would need to include a residual panethnic category to take account of the presence of these groups on the labor market status of the individual groups that are the focus of the analysis. In addition, the estimates of internal migration and immigration used in our analysis are observed for blacks, Asians, and Hispanics as panethnic categories. 
${ }^{3}$ The independent variables in these equations included age, age squared, nonrespondent household income, marital status, sex, education, disability, and school attendance; a vector of binary variables for ethnic/immigrant group affiliation, including native Asians, non-Hispanic blacks, nonHispanic whites, and Hispanics, and immigrants who have been in the United States for less than 11 years or those who have been in the United States for more than 10 years; a vector of binary variables for major occupation of respondent, including skilled white-collar, semiskilled white-collar, skilled bluecollar, and semiskilled and unskilled blue-collar; and a vector of binary variables for the product of ethnic/immigrant group affiliations and major occupation. Nonrespondent household income was included only in the jobless equation, and age squared was only included in the wage equation. Occupationally specific terms were included in estimating equations for the log odds of joblessness and the log of hourly wages for blacks, Hispanics, and Asians only if, individually, each group had at least 1,000 workers in an individual metropolitan area. This, in turn, affected the number of aggregated cases each group contributed to the total sample used to estimate Equation 1. Thus, there were 47 metropolitan areas in the PUMS with 1,000 or more blacks, 32 with 1,000 or more Hispanics, and 18 with 1,000 or more Asians. In some cases, we excluded metropolitan areas that had sufficient samples of whites and blacks but very few immigrants in the PUMS files. Further discussion of the estimation procedure and sample results for joblessness for workers in the Miami CMSA are reported in Wilson and Jaynes (www.ssc.wisc.edu/cde/cdewp/95-32.pdf).

${ }^{4}$ In 1980, the CMSA(MSA)s affected by this rule included Albany-Schenectady-Troy, Baton Rouge, Cincinnati, Denver, Detroit, Houston, Memphis, New Orleans, New York, Rochester (NY), San Antonio, Toledo, and Washington, DC. The affected CMSA(MSA)s in 1990 included Memphis, Baton Rouge, New Orleans, Washington, DC, Baltimore, Rochester (NY), Albany-Schenectady-Troy, Charlotte-Gastonia-Rock Hill, Greensboro-Winston-Salem-High Point, Toledo, Dayton-Springfield $(\mathrm{OH})$, San Antonio, Austin, Richmond-Petersburg, New York, Denver, Houston, and Philadelphia. The 
complete list of 52 metropolitan areas and the primary metropolitan statistical areas associated with the CMSAs is available from the authors upon request.

${ }^{5}$ Although the coefficients derived from estimating equations for joblessness and hourly wages might differ from those that would be estimated if the entire metropolitan population were represented, we assume they do not; in any event, we do not think this poses a serious problem because the omitted population represents in most instances less than 10 percent of the total population. We include no metropolitan areas located in New England because of the manner in which the county components were allocated on the 1990 PUMS.

${ }^{6}$ The national estimate of immigration for $1980-85$ by 16 source countries is distributed to states and counties according to the proportionate distribution of 1975-80 immigrants to states and counties by the 16 source countries. In other words, it is assumed that immigrants who arrived between 1980 and 1985 distributed themselves in the same manner geographically as those who arrived during 1975-80.

${ }^{7}$ The estimates of changes in the white population was obtained from U.S. Bureau of the Census (1990). In addition, the denominator for the estimates of net minority migration and immigration were also obtained from this source. The other variables were estimated with data from the Survey of Income and Program Participation (SIPP), 1984 and 1987 panels. Although the estimates are based on averages for the last 6 months of a calendar year (1983 or 1988), they are probably subject to greater sampling variability because of the size of the SIPP panels. Thirteen CMSA(MSA)s are not separately identified on the SIPP, including Albuquerque, Baton Rouge, Bakersfield, Baltimore, Brownsville-Harlingen (TX), Charleston (SC), Charlotte Gastonia-Rock Hill (NC-SC), Columbia (SC), El Paso, McAllen-EdinburghMission (TX), Richmond-Petersburg, and Waco. For these metropolitan areas, we use state estimates. ${ }^{8}$ However, we should emphasize once again that migration flows may be disproportionately directed to labor market areas experiencing modest to strong economic growth, potentially making it difficult to distinguish the effects of migration from effects of local economic growth. We attempt to 
control for this by including change in the size of the white population as a proxy for economic growth.

${ }^{9}$ Since the analytic model used calls for comparisons of the labor market status of immigrant groups with native workers of different ethnic backgrounds, such comparisons are only meaningful for metropolitan areas in which members of these groups are concentrated. The ethnic composition of metropolitan areas differs, however, not only with respect to the share of their populations represented by individual ethnic minority groups, but also with respect to variation in the origin and composition of the immigrant components of their populations. Thus, native workers may encounter immigrants from different origins with different migration histories, and this in turn provides the context within which they interact in local labor markets.

${ }^{10} \mathrm{An}$ issue of possible concern is whether the ethnic composition of the two immigration categories varies by metropolitan area. The distinction we make between immigrants and native ethnic populations ignores the generational relations existing between these subgroups, a connection that may be more pronounced among members of some groups in some metropolitan areas. We constructed tables (not shown) to evaluate this possibility. The results show that while the ethnic composition of the nativity groups varies by metropolitan area as expected, there are only five instances in which a specific ethnic group represents more than 50 percent of the population of either of the immigrant categories. Three of these cases involve non-Hispanic white immigrants who have been in the United States for more than 10 years. In the case of specific metropolitan areas, there are four in the Southwest in which Hispanics constitute the majority of both native and immigrant groups, and six in the East North Central and South Atlantic regions in which whites are the majority of all three groups.

${ }^{11}$ The reciprocal of the standard deviation of the mean predicted values is computed as follows: $1 / \sigma=1 / \sqrt{\sigma_{\mathrm{yt}}}{ }^{2+}{\sigma_{\mathrm{yt}+1}}^{2}$ where $\mathrm{y}$ is predicted joblessness or hourly wages, and $\mathrm{t}$ is 1980 and $\mathrm{t}+1$ is 1990 .

${ }^{12}$ The correlation matrix is available from the authors. Variables with correlations above .50 include (1) minority net migration with foreign-born share (.548), 1980 population (.647), and minority 
immigration (.683); and (2) minority immigration with foreign-born share (-.514) and 1980 population $(-.873)$ 



\section{References}

Altonji, Joseph G., and David Card. 1991. "The Effects of Immigration on the Labor Market Outcomes of Less-Skilled Natives." In Immigration, Trade, and the Labor Market, edited by John M. Abowd and Richard B. Freeman, pp. 201-234. Chicago: University of Chicago Press.

Bailey, Thomas, and Roger Waldinger. 1991a. "The Changing Ethnic/Racial Division of Labor.” In Dual City: Restructuring New York, edited by John H. Mollenkopf and Manuel Castells, pp. 43-78. New York: Russell Sage Foundation.

_. 1991b. "Primary, Secondary, and Enclave Labor Markets: A Training Systems Approach." American Sociological Review 56: 432-445.

Bean, Frank D., and Marta Tienda. 1987. The Hispanic Population of the United States. New York: Russell Sage Foundation.

Bean, Frank D., and Mark Fossett. Forthcoming. "Labor Market Dynamics and the Effects of Immigration on African Americans." In Immigration and Race, edited by Gerald Jaynes. New Haven, CT: Yale University Press.

Bonacich, Edna. 1972. “A Theory of Ethnic Antagonism: The Split Labor Market.” American Sociological Review 37: 547-559.

— 1976. "Advanced Capitalism and Black/White Race Relations in the United States: A Split Labor Market Interpretation.” American Sociological Review 41: 34-51.

Borjas, George J. 1990. Friends or Strangers: The Impact of Immigrants on the U.S. Economy. New York: Basic Books.

. 1992. "National Origin and the Skills of Immigrants in the Postwar Period." In Immigration and the Work Force, edited by George J. Borjas and Richard B. Freeman, pp. 17-47. Chicago: University of Chicago Press.

. 1994. “The Economics of Immigration.” Journal of Economic Literature 32: 1667-1717.

1998. “Do Blacks Gain or Lose From Immigration?” In Help or Hindrance? The Economic Implications of Immigration for African Americans, edited by Daniel S. Hamermesh and Frank Bear, pp. 51-74. New York: Russell Sage Foundation.

Borjas, George J., and Richard Freeman, eds. 1992. Immigration and the Work Force: Economic Consequences for the United States and Source Areas. Chicago: University of Chicago Press.

Borjas, George, Richard B. Freeman, and Lawrence Katz. 1992. "On the Labor Force Effect of Immigration and Trade." In Immigration and the Work Force, edited by George Borjas and Richard Freeman, pp. 213-244. Chicago: University of Chicago Press. 
Butcher, Kristin. 1998. "An Investigation of the Effects of Immigration on the Labor Market Outcomes of African-Americans." In Help or Hindrance? The Economic Implications of Immigration for African Americans, edited by Daniel S. Hamermesh and Frank Bear, pp. 149-181. New York: Russell Sage Foundation.

Espenshade, Thomas J. Forthcoming. "Immigrants, Puerto Ricans, and the Earnings of Native Black Males." In Immigration and Race, edited by Gerald Jaynes. New Haven, CT: Yale University Press.

Friedberg, Rachel M., and Jennifer Hunt. 1995. "The Impact of Immigrants on Host Country Wages, Employment and Growth.” Journal of Economic Perspectives 9(2): 23-44.

Frey, William H. 1995. "Immigration and Internal Migration 'Flight' from US Metropolitan Areas: Toward a New Demographic Balkanisation.” Urban Studies 32: 733-757.

Harrison, Bennett, and Barry Bluestone. 1988. The Great U-Turn: Corporate Restructuring and the Polarizing of America. New York: Basic Books.

Jaeger, David A. 1995. "Skill Differences and the Effect of Immigrants on the Wages of Natives." Washington, DC: Bureau of Labor Statistics, U.S. Department of Labor.

Kasarda, John D. 1985. "Urban Change and Minority Opportunities." In The Urban Reality, edited by Paul E. Peterson. Washington, DC: Brookings Institution.

1995. "Industrial Restructuring and the Changing Ratio of Jobs." In State of the Union, America in the 1990's. Vol. 1: Economic Trends, edited by Reynolds Farley, pp. 215-268. New York: Russell Sage Foundation.

Levy, Frank. 1987. Dollars and Dreams: The Changing American Income Distribution. New York: Russell Sage Foundation.

Light, Ivan, and Carolyn Rosenstein. 1995. Race, Ethnicity, and Entrepreneurship in Urban America. New York: Aldine de Gruyter.

Logan, John R., Richard D. Alba, and Thomas L. McNulty. 1994. "Ethnic Economies in Metropolitan Regions: Miami and Beyond." Social Forces 72: 691-724.

Mead, Lawrence M. 1992. The New Politics of Poverty: The Nonworking Poor in America. New York: Basic Books.

Muller, Thomas. 1993. Immigrants and the American City. New York: New York University Press.

Muller, Thomas, and Thomas Espenshade. 1985. The Fourth Wave: California's Newest Immigrants. Washington, DC: Urban Institute Press.

Scott, Allen J. 1996. "The Manufacturing Economy: Ethnic and Gender Division of Labor." In Ethnic Los Angeles, edited by R. Waldinger and M. Bozorgmehr, pp. 215-244. New York: Russell Sage Foundation. 
Smith, James P., and Barry Edmonston, eds. 1997. The New Americans: Economic, Demographic, and Fiscal Effects of Immigration. Washington, DC: National Academy Press.

U.S. Bureau of the Census. 1989. "Population Estimates by Race and Hispanic Origin for States, Metropolitan Areas, and Selected Counties: 1980-1985." Current Population Reports, Series P25, No. 1040-RD-1. Washington, DC: Government Printing Office.

1990. "Population Estimates for Metropolitan Statistical Areas, July 1, 1988, 1987, and 1986." Current Population Reports, Series P-26. Washington, DC: Government Printing Office.

Waldinger, Roger. 1994. "The Making of an Immigrant Niche.” International Migration Review 28: 3-30.

1996a. Still the Promised City? African-Americans and New Immigrants in Postindustrial New York. Cambridge, MA: Harvard University Press.

1996b. "Ethnicity and Opportunity in the Plural City." In Ethnic Los Angeles, edited by R. Waldinger and M. Bozorgmehr, pp. 445-470. New York: Russell Sage Foundation.

Walker, Robert, Mark Ellis, and Richard Barff. 1992. "Linked Migration Systems: Immigration and Internal Labor Flows in the United States.” Economic Geography 68: 234-248.

Welch, Finis. 1990. “The Employment of Black Men.” Journal of Labor Economics 8: S26-S74.

Wetzel, James R. 1995. "Labor Force, Unemployment, and Earnings." In State of the Union, America in the 1990's. Vol. 1: Economic Trends, edited by Reynolds Farley, pp. 59-106. New York: Russell Sage.

White, Michael J., and Lori Hunter. 1993. "The Migratory Response of Native-Born Workers to the Presence of Immigrants in the Labor Market.” Unpublished paper. Brown University.

Wilson, William J. 1996. When Work Disappears: The World of the New Urban Poor. New York: Knopf. 